\title{
PERKECAMBAHAN UREDOSPORA HEMILEIA VASTATRIX PADA EKSTRAK RIMPANG JAHE DAN KUNYIT SERTA DAUN CENGKEH DAN SIRIH
}

\author{
Cipta Ginting ${ }^{1}$
}

\begin{abstract}
Germination of Hemileia vastatrix uredospores on crude water extracts of zinger and turmeric rhizome and clove and Piper betle leaves. Coffee leaf rust caused by $H$. vastatrix especially on Arabica coffee is one of most important diseases in coffee and conventional control methods of leaf coffee rust is still unsatisfactory. The objective of this study was to determine the effect of crude water extract on the germination of $H$. vastatrix uredospores. The study was conducted from January to September 2004 in the Laboratory of Plant Pathology at Unila. In each test, treatments were arranged in a randomized complete block design with four replications. Crude water extract was prepared by homogenizing 100 g of material in $100 \mathrm{ml}$ sterilized distilled water. After being passed through four layers of sterilized cheesecloth, the mixture was defined as the aliquot (100\% extract) and dilutions were made with sterile distilled water to obtain concentrations of 2.5 to $10 \%$. Each of four materials (zinger, turmeric, clove, and Piper betle) was tested separately in five aliquot concentration levels. One $\mathrm{ml}$ of each extract was mixed with $0.25 \mathrm{ml}$ of uredospora suspension $\left(4 \mathrm{x} 10^{5}\right.$ per ml), and $0.2 \mathrm{ml}$ of the mixture was incubated. The variable was germinated uredospora (\%) that was determined under a mikroscope. The results show that significant reduction in spore germination occurred by turmeric, clove, and $P$. betle extracts at $\geq 2.5 \%$ and by zinger extract at $\geq 5 \%$. Some uredospora exposed to plant extract germinated abnormally: germ tubes shorten, swollen, or malform.
\end{abstract}

Key words : Hemileia vastatrix, coffee leaf rust, botanical fungicide

\section{PENDAHULUAN}

Penyakit karat daun yang disebabkan oleh Hemileia vastatrix B. et Br. menyebabkan kerusakan pada tanaman kopi dan dapat membawa kerugian ekonomi khususnya pada kopi arabika (Coffea arabica L.). Masalah ini cenderung makin berat sejalan dengan peningkatan luas areal kopi arabika, yang dilaksanakan sebagai upaya peningkatan daya saing kopi nasional di pasaran internasional. Untuk mencegah atau mengurangi kerugian itu, penyakit ini dikendalikan dengan mengaplikasikan fungisida sintentik terutama tembaga dan beberapa fungisida organik nonsistemik dan yang sistemik (Semangun, 2000).

Penggunaan fungisida sintetik secara intensif menambah biaya produksi menjadi tinggi dan dapat meninggalkan residu pada produk yang dapat merugikan kesehatan konsumen serta dapat membawa pengaruh negatif terhadap lingkungan. Masalah biaya produksi dan residu fungisida pada produk mempengaruhi daya saing industri kopi nasional, khususnya dengan semakin banyak negara pesaing pada pasar internasional.

Untuk mengurangi dampak residu fungisida sintetik digunakan fungisida botani. Berbagai tumbuhan mengandung senyawa aktif dan dilaporkan bahwa sebagian menunjukkan efek fungisida serta dapat menekan jamur patogen (Dhalimi et al., 1999; Darsam et al., 1994; Grainge and Ahmad, 1988; Manohara et al., 1994). Ginting et al. (2004) melaporkan terjadinya penurunan keterjadian penyakit pada cakram daun kopi di laboratorium akibat aplikasi eksrak air daun cengkeh dan sirih serta rimpang jahe dan kunyit.

Penelitan ini bertujuan untuk mengetahui pengaruh ekstrak air daun cengkeh dan sirih serta rimpang jahe dan kunyit terhadap perkecambahan uredospora $H$. vastatrix.

\section{METODE PENELITIAN}

Penelitian ini dilaksanakan dari Januari sampai September 2004 di Laboratorium Penyakit Tumbuhan Unila. Bahan tumbuhan (rimpang jahe dan kunyit serta daun cengkeh dan sirih) dibersihkan dengan air keran kemudian dibilas dengan akuades steril. Sebanyak 100 g bahan diblender dalam $100 \mathrm{ml}$ akuades steril. Cairan yang dihasilkan disaring dengan tiga lapis kain kasa steril. Ekstrak yang diperoleh didefinisikan sebagai alikuot (ekstrak 100\%). Dari

${ }^{1}$ Dosen Jurusan Proteksi Tanaman,Fakultas Pertanian, Universitas Lampung, Jl. Prof Sumantri Brojonegoro No.I,Bandar Lampung 35145 
alikuot ini dibuat ekskrak dengan konsentrasi 2,5 sampai $10 \%$.

Perlakuan disusun dalam rancangan kelompok dengan tiga nampan pengelompok. Prosedur pengujian dimodifikasi dari Dhingra and Sinclair (1985), yaitu dengan mencampurkan $1 \mathrm{ml}$ ekstrak pada konsentrasi tertentu dan $0,25 \mathrm{ml}$ suspensi uredospora (4 x $10^{5}$ per $\mathrm{ml}$ ). Sebanyak $0,2 \mathrm{ml}$ campuran disebar-ratakan pada permukaan bawah cakram daun kopi yang diletakkan pada busa plastik steril. Untuk menjaga agar kelembaban $100 \%$, busa tersebut ditetesi akuades steril dan nampan ditutup dengan kaca transparan. Inkubasi dilakukan pada suhu 23-26 (dalam ruangan ber-AC). Di samping uji pada permukaan daun, ekstrak daun cengkeh dan rimpang kunyit diuji pada gelas preparat. Untuk pengamatan, uredospora pada permukaan cakram daun diambil dengan menggunakan skalpel dan yang pada gelas preparat diambil dengan mikropipet sebanyak $50 \mu \mathrm{l}$ campuran, kemudian disebar-ratakan pada gelas preparat. Uredospora diamati di bawah mikroskop dengan pembesaran 100 dan 400 kali. Data diolah dengan sidik ragam dan nilai tengah antarperlakuan dipisahkan dengan Uji Duncan $(\mathrm{P} \leq 5 \%)$.

\section{HASIL DAN PEMBAHASAN}

Uredospora didefinisikan telah berkecambah jika tabung kecambahnya setidaknya sama dengan panjang uredospora. Sebagian besar perkecambahan uredospora berlangsung setelah 4 jam inkubasi. Tabung kecambah yang dibentuk pada perlakuan kontrol (aquades steril) halus dan cenderung lurus. Uredospora yang terdedah pada ekstrak tumbuhan tidak berkecambah atau berkecambah dengan tidak normal, yaitu tabung kecambah tidak normal: berbentuk gada, pendek, bengkak.

Hasil penelitian menunjukkan bahwa ekstrak air rimpang jahe, rimpang kunyit, daun cengkeh, dan daun sirih secara nyata $(\mathrm{P}<0,05)$ mengurangi persentase uredospora yang berkecambah (Gambar 14). Makin tinggi konsentrasi pada semua jenis ekstrak menyebabkan makin kecil proporsi uredospora yang berkecambah. Aras konsentrasi esktrak terendah yang secara nyata menekan perkecambahan uredospora umumnya ialah 2,5\%, kecuali ekstrak jahe yang efektif pada aras $\geq 5,0 \%$.

Pengujian ekstrak rimpang kunyit dan daun cengkeh dilakukan dua kali, yaitu pada cakram daun dan gelas preparat. Tempat pengujian yang berbeda (cakram daun dan gelas preparat) memberikan hasil yang konsisten, yaitu ekstrak efektif pada aras konsentrasi yang paling rendah (2,5\%). Jika dilihat data hasil pengamatan pada perlakuan kontrol $(0 \%)$ pada pengujian pada cakram daun, persentase uredospora yang berkecambah tidak meningkat dengan perpanjangan masa inkubasi (Gambar 1A, 2A, 3, dan 4). Hal yang berbeda diperoleh pada gelas preparat bahwa persentase uredospora nampaknya meningkat dengan perpanjangan masa inkubasi, meskipun tidak dianalisis apakah peningkatan angka tersebut nyata secara statistika (Gambar 1B dan 2B). Hal ini mungkin terkait dengan proses perkecambahan dan penetrasi. Uredopora yang berkecambah akan membentuk apresorium dan hifa penetrasi yang kemudian memasuki jaringan daun melalui stomata (Agrios, 2005; Semangun, 2000). Tampaknya sebagian uredospora yang telah berkecambah pada permukaan daun kopi tertahan karena hifa penetrasi mungkin telah memasuki jaringan daun sehingga tidak terambil sebagai terok sehingga menurunkan angka perkecambahan uredospora pada 8 dan 12 jam setelah inkubasi. Permukaan daun digunakan sebagai media pengujian untuk tujuan meniru kondisi di lapangan. Bagaimanapun, pada semua set percobaan baik pada permukaan daun maupun pada gelas preparat, ekstrak air dari keempat jenis tumbuhan secara nyata menurunkan perkecambahan uredospora.

Data hasil penelitian juga menunjukkan variasi persentase perkecambahan uredospora pada perlakuan kontrol (Gambar 1-4). Urodospora yang berkecambah 4 jsi pada perlakuan kontrol pada pengujian ekstrak jahe, kunyit, cengkeh, dan sirih pada cakram daun berturut-turut sebanyak 22,0; 38,3; 44,7; dan 15,0\%. Hal yang sama terjadi pada gelas preparat (Gambar 1B dan 2B). Hal ini mungkin karena kondisi uredospora tidak sama antarpercobaan. Uredospora yang digunakan pada penelitian ini berkembang pada daun di kebun kopi, tidak dihasilkan dari perkembangbiakan di bawah kondisi terkontrol di laboratorium. Pengujian empat ekstrak yang dilaporkan ini tidak dilakukan pada waktu yang sama dengan suspensi uredospora yang berbeda. Meskipun demikian, setiap ekstrak dilakukan pada satu percobaan dengan suspensi uredospora yang sama.

Hasil percobaan untuk mengetahui pengaruh konsentrasi ekstrak terpilih terhadap perkecambahan uredospora menunjukkan bahwa, pada konsentrasi yang relatif rendah (umumnya 2,5\%) ekstrak dapat mencegah perkecambahan uredospora. Hasil yang telah diperoleh menunjukkan bahwa ekstrak yang diuji pada penelitian ini secara konsisten menurunkan 

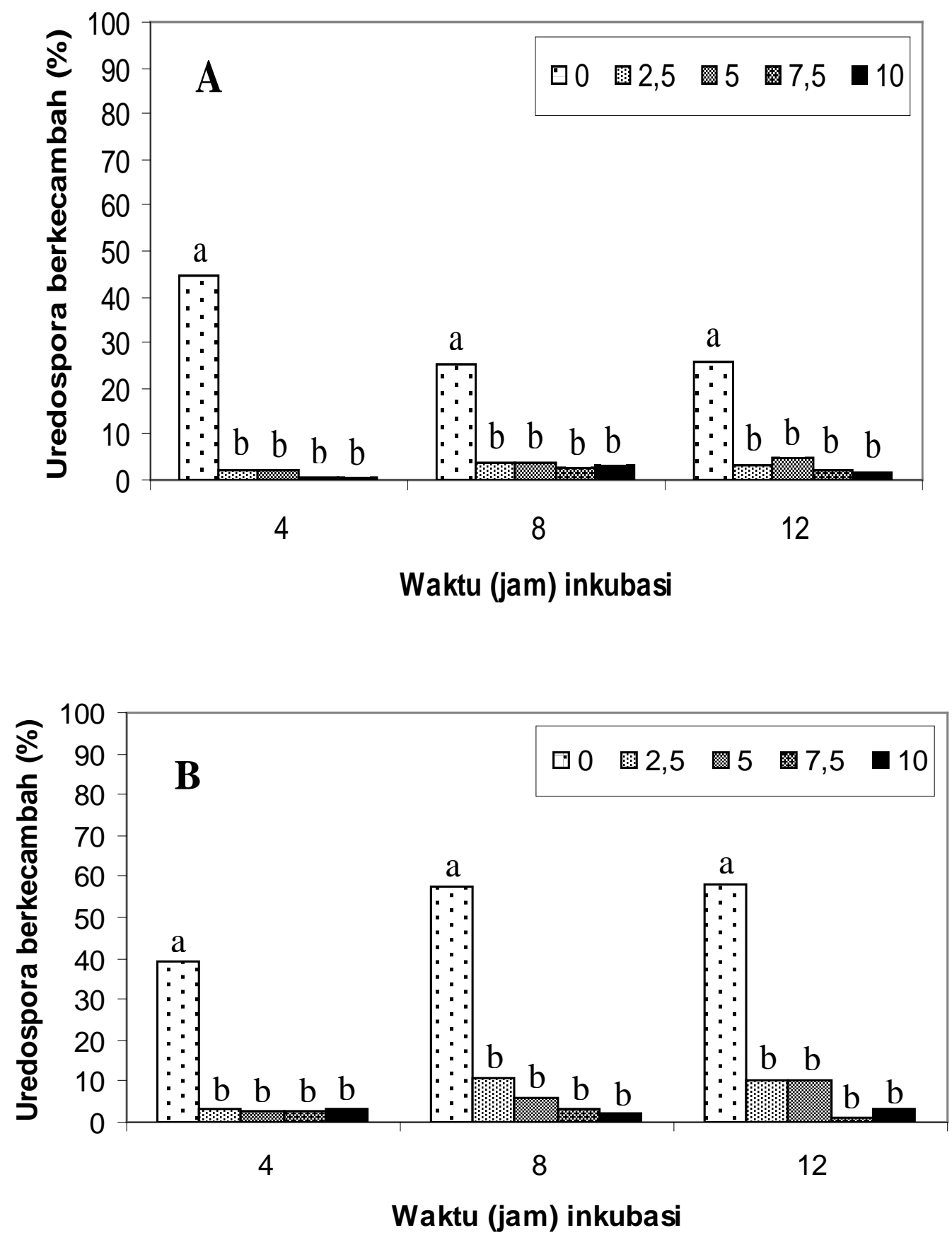

Gambar 1. Pengaruh ekstrak air daun cengkeh pada konsentrasi $0-10 \%$ terhadap perkecambahan uredospora H. Vastatrix pada cakram daun (A) dan gelas preparat (B). Huruf yang berbeda di atas batang menunjukkan perbedaan nyata $(\mathrm{P} \leq 0,05)$ persentase perkecambahan uredospora pada masing-masing waktu inkubasi. 

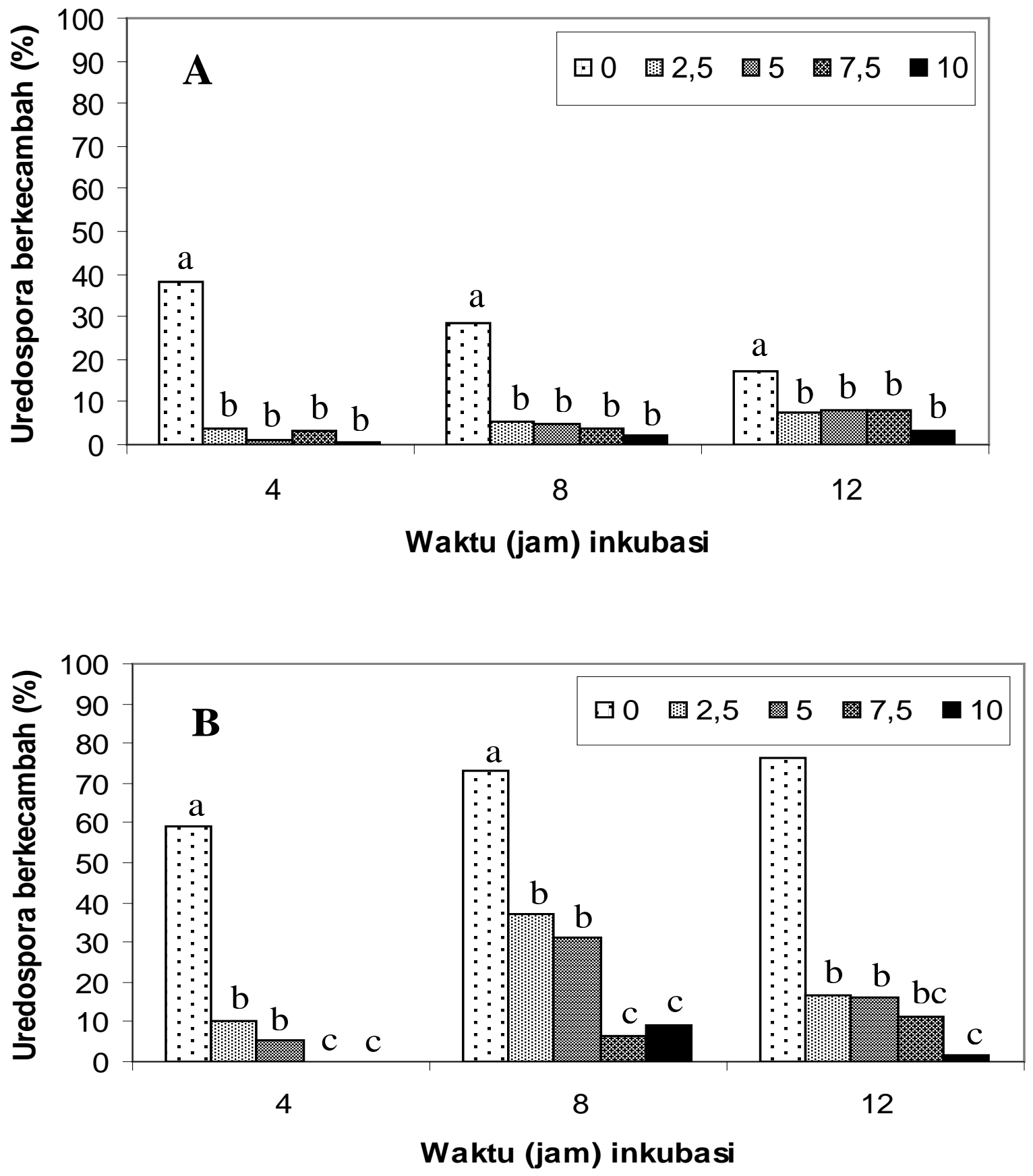

Gambar 2. Pengaruh ekstrak air rimpang kunyit pada konsentrasi $0-10 \%$ terhadap perkecambahan uredospora H. Vastatrix pada cakram daun (A) dan gelas preparat (B). Huruf yang berbeda di atas batang menunjukkan perbedaan nyata $(\mathrm{P} \leq 0,05)$ persentase perkecambahan uredospora pada masing-masing waktu inkubasi. 


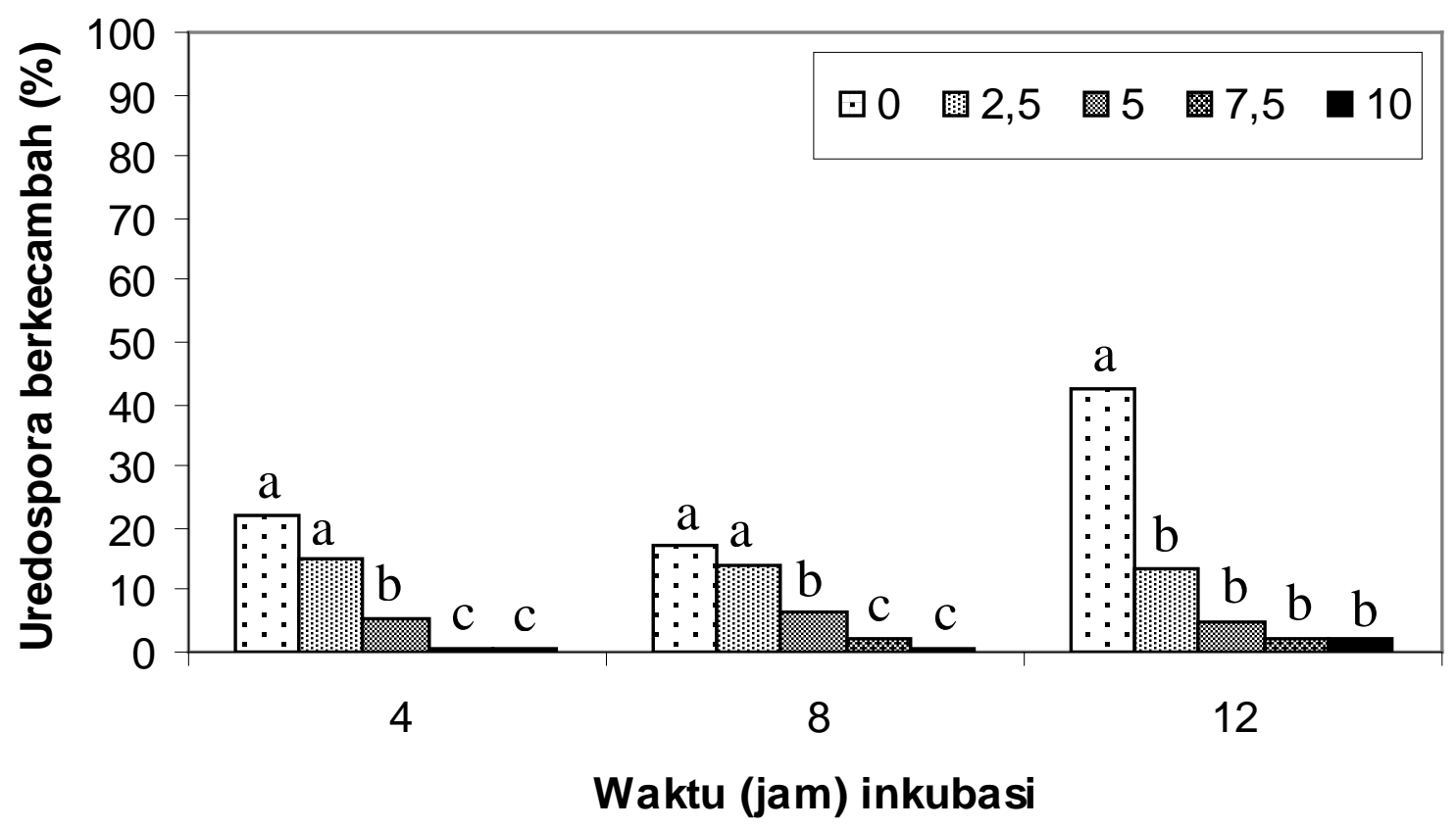

Gambar 3. Pengaruh ekstrak air rimpang jahe pada konsentrasi 0 - 10\% terhadap perkecambahan uredospora $H$. Vastatrix pada cakram daun. Huruf yang berbeda di atas batang menunjukkan perbedaan nyata $(\mathrm{P} \leq 0,05)$ persentase perkecambahan uredospora pada masing-masing waktu inkubasi.

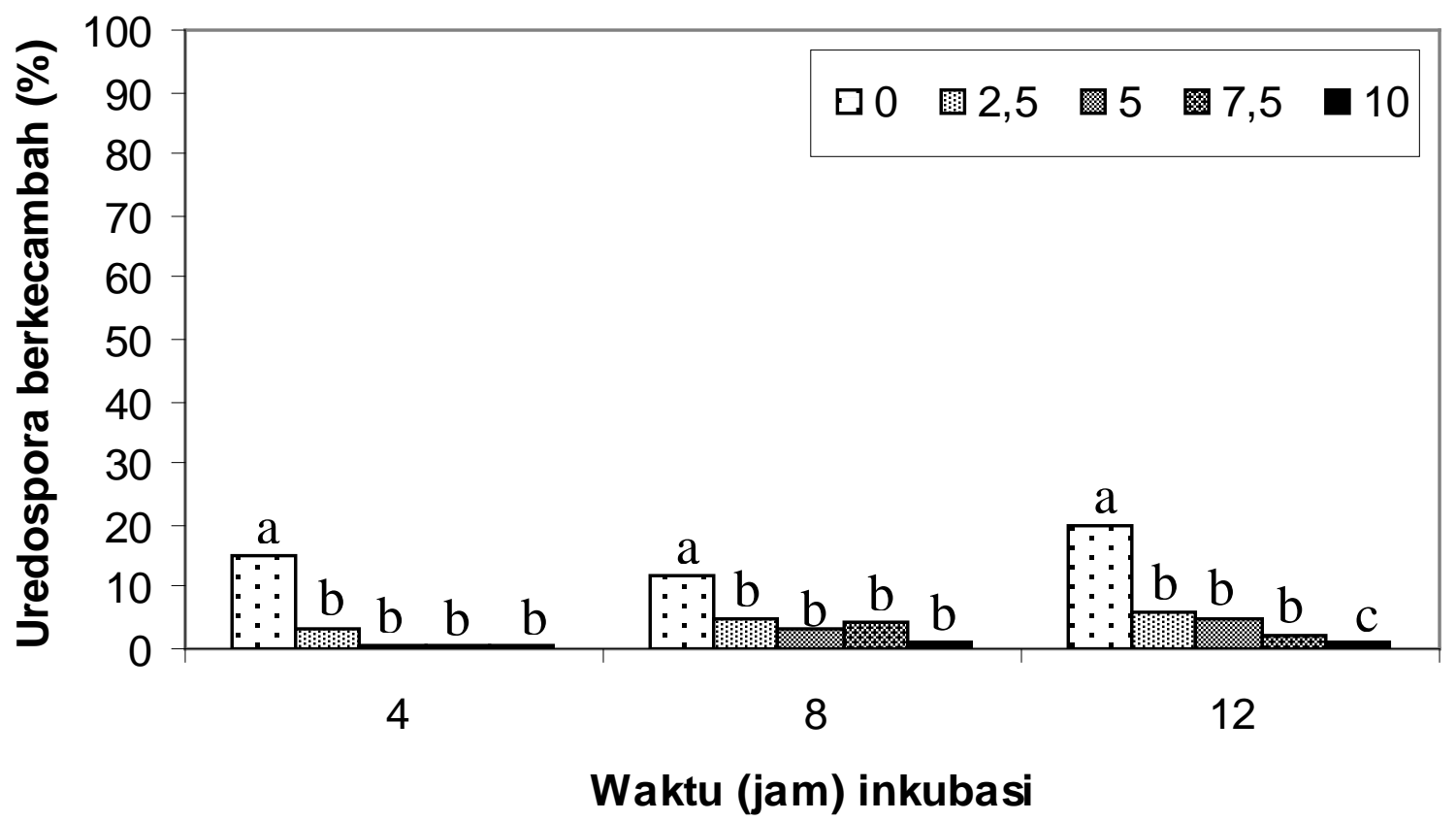

Gambar 4. Pengaruh ekstrak air daun sirih pada konsentrasi 0 - 10\% terhadap perkecambahan uredospora $H$. Vastatrix pada cakram daun. Huruf yang berbeda di atas batang menunjukkan perbedaan nyata $(\mathrm{P} \leq 0,05)$ persentase perkecambahan uredospora pada masing-masing waktu inkubasi. 
persentase perkecambahan uredospora, yang merupakan struktur reproduktif yang berperan dalam penyebaran penyakit. Di samping itu, ekstrak tersebut efektif dalam menurunkan keterjadian penyakit di laboratorium (Ginting et al., 2004). Hal ini menunjukkan potensi ekstrak untuk mengendalikan penyakit karat daun kopi.

Mekanisme penghambatan perkecambahan uredospora pada penelitian ini belum diketahui. Diduga hal itu terjadi akibat senyawa tertentu yang terdapat pada ekstrak air tumbuhan meskipun senyawa bioaktif yang mempunyai efek fungisida yang dominan belum diketahui. Daun sirih mengandung minyak atsiri sebanyak 4,2\% yang mengandung senyawa fenol yang disebut betlephenol, kavikol, seskuiterpen, dll. Daun cengkeh mengandung minyak atsiri sebesar 1\% yang mengandung eugenol $80-82 \%$, asetileugenol, dll. Tangkai dan bunga cengkeh mengandung minyak atsiri berturut-turut sebesar 5-6 dan 1-20\%. Rimpang jahe mengandung minyak atsiri yang terdiri atas fulandren, d-kamfen, zingiberen dan zingiberon. Rimpang kunyit mengandung fellandren, sineol, zingiberin, kampen, demetoksikurkumin, biodemetoksikurkumen, tanin, seskulterpene, kurkumin, dll. (Kartasapoetra, 1996; Sastroamidjoyo, 1998; Scheffer and Jansen, 1999). Untuk mengetahui senyawa kimia yang paling berperan perlu diadakan penelitian lebih lanjut. Manohara et al. (1994) menunjukkan bahwa senyawa kimia pada minyak atsiri cengkeh yang paling berperan menekan pertumbuhan Phytophthora capsici ialah eugenol. Tampaknya, penyiapan ekstrak air kasar dengan prosedur ini melepas senyawa biaktif ke dalam air dan menunjukkan efek fungisida.

\section{SIMPULAN}

Ekstrak rimpang jahe, rimpang kunyit, daun cengkeh, dan daun sirih secara nyata $(\mathrm{P} \leq 0,05)$ mengurangi persentase uredospora yang berkecambah. Perlakuan nyata tersebut terjadi pada perlakuan ekstrak kunyit, cengkeh, dan sirih pada konsentrasi $\geq 2,5 \%$ dan pada perlakuan ekstrak jahe pada konsentrasi $\geq 5,0 \%$.

Tempat pengujian ekstrak daun cengkeh dan kunyit yang berbeda (cakram daun dan gelas preparat) memberikan hasil yang konsisten, yaitu ekstrak efektif pada aras konsentrasi 2,5\%.

\section{SANWACANA}

Penelitian ini terlaksana berkat dukungan dana dari Proyek Hibah Bersaing Dikti Depdiknas. Penulis menyampaikan terima kasih kepada Pengelola Proyek Hibah Bersaing dan Pimpinan Lembaga Penelitian Unila sehingga penelitian sejauh ini dapat berlangsung. Ucapan terima kasih juga disampaikan kepada Subli Mujim dan Rusdi Evizal yang memberi masukan selama pelaksanaan penelitian, dan kepada Yusuf, Farida Ariani, Tri Maryono, Paryadi yang telah membantu di laboratorium dan di lapangan.

\section{DAFTAR PUSTAKA}

Agrios, G.N. 2005. Plant Pathology. $5^{\text {th }}$ Ed. Elsevier Academic Press, Burlington, M.A.

Darsam, L. Soesanto \& C. Pudjiastuti. 1994. Kajian pendahuluan cairan perasan daun sirih, lada, dan cabe jawa terhadap pertumbuhan jamur Phytophthora palmivora. Dalam Prosiding Seminar Hasil Penelitian dalam Rangka Pemanfaatan Pestisida Nabati. Bogor, 1 - 2 Desember. Balittro, Bogor. Hlm. 65 - 69.

Dhalimi, A. D. Sitepu \& D. Soetopo. 1999. Status dan Perkembangan Penelitian Pestisida Nabati. Makalah disampaikan pada Forum Komunikasi Ilmiah Pemanfaatan Pestisida Nabati. Bogor, 9 - 10 Nopember. 12 hlm.

Dhingra, O.D. \& J.B. Sinclair. 1985. Basic Plant Pathology Methods. CRC Press, Inc., Boca Raton, Florida.

Ginting, C., S. Mujim, \& R. Evizal. 2004. Uji pendahuluan pengaruh ekstrak air dari tumbuhan terhadap keterjadian karat pada cakram daun di laboratorium. J. HPT Tropika 4:41-51.

Manohara, D., D. Wahyuno \& Sukamto. 1994. Pengaruh tepung dan minyak cengkeh terhadap Phytophthora, Rigidoporus, dan Sclerotium. Dalam Prosiding Seminar Hasil Penelitian dalam Rangka Pemanfaatan Pestisida Nabati. Bogor, 1-2 Desember. Balittro, Bogor. Hlm. 19-27. 
Grainge, M. \& S. Ahmad. 1988. Handbook of Plants with Pest-Control Properties. John Willey and Sons. New York.

Kartasapoetra, G. 1996. Budidaya Tanaman Berkhasiat Obat. Rineka Cipta, Jakarta.

Muhlisah, F. 1999. Temu-temuan dan Empot-empot: Budidaya dan Manfaatnya. Kanisius, Yogyakarta.
Sastroamidjoyo. 1998. Obat Asli Indonesia. Dian Rakyat, Jakarta.

Scheffer, J.J.C. \& P.C.M. Jansen. 1999. Alpinia alanga (L.) Wild. Dalam C.C. de Guzman and J.S. Siemonsma (eds.) Spices. Backhuys Pub., Leiden.

Semangun, H. 2000. Penyakit-penyakit Tanaman Perkebunan di Indonesia. Edisi revisi. Gadjah Mada University Press, Yogyakarta. 